\title{
Understanding New Service Development and Service Innovation through Innovation Modes
}

\author{
Ida Gremyr, Lars Witell, Nina Löfberg, Bo Edvardsson and Anders Fundin
}

\section{Linköping University Post Print}

\section{Tweet}

N.B.: When citing this work, cite the original article.

Original Publication:

Ida Gremyr, Lars Witell, Nina Löfberg, Bo Edvardsson and Anders Fundin, Understanding New Service Development and Service Innovation through Innovation Modes, 2014, The journal of business \&amp; industrial marketing, (29), 2, 123-131.

http://dx.doi.org/10.1108/JBIM-04-2012-0074

Copyright: Emerald

http://www.emeraldinsight.com/

Postprint available at: Linköping University Electronic Press

http://urn.kb.se/resolve?urn=urn:nbn:se:liu:diva-105395 


\section{UNDERSTANDING NEW SERVICE DEVELOPMENT AND SERVICE INNOVATION THROUGH INNOVATION MODES}

\section{ABSTRACT}

\section{Purpose}

The purpose of this paper is to explore the role of innovation modes in understanding challenges of integrated NSD and NPD, and the use of structured NSD processes in manufacturing firms.

\section{Design/Methodology/Approach}

The research is based on a two-stage multiple case study. The first stage is an interview study of 17 key informants representing manufacturing firms in the machine industry. The second stage is an in-depth study of three service innovations at three manufacturing firms based on 16 interviews with key informants.

\section{Findings}

The results of the study show that NSD processes are often more structured if the service is developed separately from the product. The fact that different innovation modes benefit from varying degrees of structure in the development process means that integrated service development can be challenging. Furthermore, service innovations often follow a trajectory of innovation modes before succeeding in the market. Some innovation modes occur within the NSD process, while others occur outside the process. One success factor for NSD is the fit between the innovation modes and the NSD process, rather than the NSD process per se.

\section{Originality/Value}


This research uses innovation modes to explain why NSD in manufacturing firms is often performed on an ad hoc basis, and how service innovations go through a trajectory of innovation modes. In this way, the study contributes to theory development of service innovation, and specifically service innovations in manufacturing firms.

Keywords: New Service Development, Service Innovation, Innovation Modes, Multiple Case Study, Manufacturing Firms

Article Classification: Research Paper 


\section{INTRODUCTION}

New technology alone is often not sufficient to differentiate the offerings of manufacturing firms (Gebauer et al., 2011; Kowalkowski et al., 2012). Instead, a competitive advantage is created by combinations of products and services, so-called hybrid offerings (Ulaga and Reinartz, 2011). Therefore, the challenges that manufacturing firms face are not only to invent new technological solutions to compete and grow, but also to establish service strategies and put them into practice through new service development (NSD) and service operations (Gebauer et al., 2010). Nonetheless, few insights exist regarding how manufacturing firms can use NSD to build a competitive advantage through service innovations (Ostrom et al., 2010; Santamaria et al., 2012).

An early research stream on service infusion in manufacturing firms was the separation or integration of the service business with the traditional business (Oliva and Kallenberg, 2003; Neu and Brown, 2005). Recently, this debate has shifted to how NSD is integrated with, or separated from, New Product Development (NPD). Integrating NSD with NPD appears to be beneficial for some services, but not all (Gebauer et al., 2008). Specific NSD processes for manufacturing firms have been suggested (Kindström and Kowalkowski, 2009), many of which use fewer stages than NPD processes, but many services are still developed outside the formal NSD process (Gremyr et al., 2010). Questions remain as to whether NSD in manufacturing firms should be performed in the NPD process or in a separate NSD process, or whether everything should be viewed as service innovation and the NPD and NSD processes should be replaced with a new process.

Research on innovation in manufacturing firms is based on the introduction of new technology and improvement in product performance. Value is viewed through 
attributes and functions rather than as being co-created with a customer (Gustafsson et al., 2010; Hsu, 2011). Consequently, innovations are often designed to improve product or service performance, rather than to improve prerequisites for value co-creation in a customer relationship. In line with Gallouj and Weinstein (1997) we view service innovation as any change that affects one or more service characteristics. Because new services differ from products in their innovation modes (Gallouj and Weinstein, 1997), service innovation cannot be explained by theory developed from observations of products (Gadrey et al., 1995).

Our research is positioned within research on service innovation in manufacturing firms, specifically on the notion of innovation modes. An innovation mode represents a specific type of change in the service characteristics of a specific service, or the creation of new service characteristics for a service (Gallouj and Weinstein, 1997). This helps us overcome the materiality and technology bias that has characterized much of the research on service innovation (Gallouj and Savona, 2009). The purpose of this paper is to explore the role of innovation modes in understanding challenges of integrated NSD and NPD and the use of structured NSD processes in manufacturing firms. Integrated service development refers to the integration of NSD and NPD into a single process. This paper reports on a two-stage research study based on 33 interviews with key informants; a multiple case study of 17 manufacturing firms and an in-depth study of three service innovations at SKF, Volvo Buses, and Volvo Trucks.

\section{THEORETICAL FRAMEWORK}

The main concepts in our theoretical framework are NSD, service innovation, and innovation modes. NSD should aim to create new markets by innovating service provision (Berry et al., 2006) and by helping customers to co-create value (Bettencourt and Brown, 2013). Previous research has shown that two critical dimensions for 
developing service innovations are the degree to which NSD and NPD are integrated, and the degree of structure of the NSD process (Gebauer et al., 2006; 2008). Furthermore, we argue that service innovations often pass through a number of innovation modes before succeeding in the market.

\section{NSD in Manufacturing Firms}

Manufacturing firms that develop services must perform activities related to both product and service innovation (Gebauer et al., 2008). Services may be developed at the same time as a product in integrated service development, or independently in separated service development (Gebauer et al., 2008). Gebauer et al. (2011) showed that the payoffs of innovations are larger for firms that either use product or service differentiation for their offerings. One possible explanation for this is that sharing resources between innovation of products and services can mean that neither business has sufficient resources for innovation activities.

Gebauer et al. (2008) studied firms in German and Swiss industry and found that the development of product-related services was often integrated into NPD, whereas customer services were often developed separately. In addition, customer services were often developed in an unsystematic way, targeting a solution for a specific customer. Further empirical research shows that although NSD processes exist, they are seldom applied in practice (Gremyr et al., 2010). The NSD process is often perceived as a hurdle for manufacturing firms since service innovation "just happens" (Martin and Horne, 1992). Many manufacturing firms are striving to increase their focus on services, and their service offerings are becoming more advanced (Oliva and Kallenberg, 2003; Mathieu, 2001). Despite the increased number of service offerings in many manufacturing firms, NSD processes remain unsystematic (Gebauer, 2007). 
Gebauer et al. (2006) found that manufacturing firms with high service revenues performed market-oriented service development in a clearly defined NSD process. Three stages of the NSD process were identified: identification of market needs, development of new services, and market introduction. Kindström and Kowalkowski (2009) divided the NSD process into four stages: market sensing, development, sales, and delivery. Both NSD processes have fewer stages than a standard NPD process; this finding is consistent with research on NSD in service firms (see, e.g., Griffin, 1997). Fischer et al. (2009) argued that a manufacturing firm should align its NSD process with its service strategy and offerings, which involves using different stages and methods depending on the service strategy and the offering (Gebauer, 2008).

\section{Service Innovation}

Theories developed for the product innovation are often suggested to cover innovation for services; that is, an assimilation perspective (Chen et al., 2009). An alternative perspective is to view service innovation as a special case of innovation; that is, a demarcation perspective (Möller et al., 2008). However, there are exceptions when adapting a synthesis perspective where service innovation is taken as the point of departure (Gallouj and Savona, 2009). The introduction of the service dominant (SD) logic of marketing (Vargo and Lusch, 2004; 2008) has led to greater interest from marketing scholars in the synthesis perspective. The widening of the service innovation concept carries risks, however, as it can make the concept less relevant and less focused (Toivonen and Tuominen, 2009).

Toivonen and Tuominen (2009) suggested that service innovation involves changes in practice, offers value to the provider, is new to others than just the firm, and is reproducible. We argue that Toivonen and Tuominen (2009) focused too much on the provider perspective and, in so doing, lose the customer perspective. In contrast, 
Gustafsson et al. (2012) suggested that a service innovation is often manifested as a change in the competencies of the manufacturing firm and the customer, either in the prerequisites of the offering or in what the customer co-creates. Salunke et al. (2011) emphasized that a service innovation should result, either directly or indirectly, in value for both the firm and its customers. We view innovation as changes in service characteristics (Gallouj and Weinstein, 1997). The service characteristics are the provider's direct competencies, clients' competencies, material and immaterial technical characteristics, and final users' value or service characteristics (Gallouj and Weinstein, 1997; Saviotti and Metcalfe, 1984).

\section{Innovation Modes}

A Lancasterian view of service can operationalize a rich set of innovation modes (Lancaster, 1966; Gallouj and Savona, 2009); an innovation mode representing a specific type of change in the service characteristics. Based on this view, Gallouj and Weinstein (1997) identified six modes of innovation: radical innovation, improvement innovation, incremental innovation, ad hoc innovation, recombinative innovation, and formalization innovation.

A radical innovation occurs when the set of underlying characteristics is changed. This often involves a change to the entire service system and major changes in several service characteristics. An improvement innovation occurs when only the quality of some of the elements of the service characteristics increases without changing the

structure of the service system. In a similar vein, an incremental innovation is characterized by adding, eliminating, or substituting a new characteristic. In a formalization innovation, one or more characteristics are formalized or standardized. This can be described as "putting the service characteristics 'into order,' specifying 
them, making them less hazy, making them concrete, giving them shape" (Gallouj and Weinstein, 1997, p. 553).

Innovations may arise in response to a client problem, which changes the providers' competency and service characteristics. These are ad hoc innovations. The most important feature of these innovations is an adaptation that responds to the specific client's problem. Ad hoc innovations challenge the basic principle that innovations have more than one specific application (Schumpeter, 1974). Recombinative innovations are limited to changes in the service or technical characteristics and come in two distinct forms; combining characteristics of one or more services, or breaking apart characteristics of a pre-existing service (Gallouj and Savona, 2009).

Viewing innovation as a process enables it to be planned, intentional, or unintentional, which means that it is emergent (Gallouj and Savona, 2009; Toivonen and Tuominen, 2009). Hence, a service innovation can pass through one or several innovation modes before reaching the market. Gallouj and Weinstein (1997) argued that even though recombinative innovation is most common for services, each individual innovation follows a unique trajectory. In line with this, Toivonen and Tuominen (2009) identified a number of cases in which different innovation modes follow each other in the development of a new service. Their study identifies trajectories including ad hoc innovation followed by formalization innovation.

Barras (1986) showed that service innovations often do not follow a traditional product life cycle. He suggested a "reverse product cycle"; that is, a specific trajectory that consists of three phases. In the first phase, new technology is introduced that leads to improved efficiency of the existing service delivery process. Second, service quality is improved. Third, the product becomes the focus, rather than the process. Gallouj and Weinstein (1997) argued that this innovation trajectory is not universal for services. 
Instead, the "reverse product cycle" has been argued only to take into account the technological characteristics of innovation that might lead to an underestimation of the non-technological innovation that takes place in services (Gallouj and Savona, 2009).

\section{RESEARCH METHODOLOGY}

To study NSD in manufacturing firms, a multiple case study approach was used (Eisenhardt, 1989; Meredith, 1998). Below, we elaborate on the design of the case study, the data collection, and the analysis.

\section{A Multiple Case Study}

The case study approach was chosen due to its ability to capture episodes, actions, and values and interactions between a phenomenon and its context (Bryman, 1988; Dubois and Gadde, 2002). The phenomena in this study are NSD and service innovation in the context of manufacturing firms. Studying multiple cases provide a stronger base for theory building (Yin, 1994) and enables a conceptual contribution (Siggelkow, 2007).

We started by performing a multiple case study of 17 manufacturing firms in the machine industry. The subject under investigation in this part of the empirical investigation is the organization of NSD. Based on this analysis, three specific service innovations were identified. They were chosen as in-depth case studies to better understand service innovation in manufacturing firms. In this part, development of the specific service innovations was the subject under investigation.

\section{Data Collection and Analysis}

To understand how manufacturing firms organize for NSD, we identified a number of cases in the machine industry. We looked specifically at large manufacturing firms with more than 500 employees, since such firms are large enough to deal with NSD, yet small enough to identify a manager responsible for NSD. We identified 23 such 
manufacturing 17 of which agreed to participate, for further details see Fundin et al. (2012). The main method of data collection was semi-structured interviews with managers. Seventeen interviews, lasting between 45 and 150 minutes, were conducted, recorded and transcribed.

Based on the results, an in-depth multiple case study was designed to study three service innovations at SKF, Volvo Buses and Volvo Trucks, see also Gremyr et al. (2010). Data for the case studies came from archival records and interviews with innovation originators, NSD staff, sales managers, service managers, and customers. A total of 16 interviews were conducted, lasting between one and two hours. Seven interviews were conducted at SKF, six at Volvo Buses, and three at Volvo Trucks. The interviews were recorded and transcribed. Information was sought in the areas of service innovation, NSD, the service's relationship to the product, sales and service provision, and reasons for the service innovation's success or failure. The data analysis was based on detailed case study write-ups (Eisenhardt, 1989) for each firm; the writeups were the basis of a thematic analysis that focused on the development process and innovation modes. Data analysis was carried out jointly to achieve complementary insights and enhanced confidence in the findings (Meredith, 1998).

\section{RESULTS}

This section starts by looking at issues related to the separation or integration of NSD and NPD, and then on three specific service innovations at SKF, Volvo Buses, and Volvo Trucks.

\section{Separated or Integrated Service Development}

Approximately half of the 17 machine industry firms studied claimed that they had integrated NSD and NPD (see Figure 1). This meant that there were activities related to 
NSD in each stage of the NPD process. These activities were often product-centered and included services such as spare parts and maintenance contracts. As one manager put it, "we try to infuse the idea that when we develop products, we develop them so that they can be serviced." When it came to describing NSD per se, the practices and methods were mostly performed on an ad hoc basis. One service manager suggests, "We do not have the right competences. But, it can be a bit sensitive to say this out loud. I have used a firm that has competence in this area, it is their specialty". The same manager went on to say, "as soon as the work crosses an organizational border, work is a bit more difficult". Since many services need a value network to gather the competences needed for service provision, the problems with integrated service development limit the potential for service innovation (see, e.g., Kowalkowski et al., 2013).

- Insert Figure 1 about here -

In manufacturing firms that perform NSD separately from NPD, service development mostly took place in a structured development process. This process often had similarities with the NPD process of the firm. One manager describes a traditional stage-gate process as follows: "we use a limited amount of resources to come to a decision at a gate (business case), there we decide if we should initiate a project where we actually develop the service". In one of the cases, there have been problems in designing a process for separated service development. The first NSD process was an adaption of the firm's NPD process. The rigidity of the process made it difficult to run small projects with short lead times. The second NSD process was a software development process that consisted of several stages: pre-study, concept study, development, final development, industrialization, and deployment. The large number of stages and a lack of NSD methods limited the success of the process. Based on these experiences, the third NSD process was developed, which contained five stages and a 
large toolbox with NSD methods for each development stage. The development of the NSD process in this firm over time shows the difficulties in finding the right degree of structure of the NSD process.

\section{Three service innovations}

Reflecting on the data on separation or integration of NSD and NPD, there appear to be certain challenges in following a structured NSD process when integrated with the NPD process. To further understand these challenges, three service innovations at SKF, Volvo Buses, and Volvo Trucks are described and elaborated on.

\section{Asset Efficiency Optimization at SKF}

Asset Efficiency Optimization (AEO) can be described as a process of achieving maximum efficiency and effectiveness from maintenance activities. AEO is "an umbrella term for optimizing a facility, and for that we have a number of tools". The specific content of AEO can vary between customers, ranging from a one-shot analysis of the customers' maintenance work to a long-term contract for SKF to manage parts of its maintenance activities.

Over the years, SKF has had both an NPD and an NSD process. The NPD process had several stages and detailed methods, while the NSD process had much less detail. However, AEO was not developed through a structured NSD process, but instead evolved through a series of initiatives over time linked to SKF's transition toward a more service-oriented manufacturing firm. The AEO concept was partly created with service specialists from service firms acquired by SKF, and one interviewee described the new employees as " $a$ bit wild and we learned from that, they were more of entrepreneurs". The interviewee continued: "One key was that we understood that those black boxes with condition monitoring and our excellent bearings and all that, it had no 
effect out there if you didn't educate the customer in understanding this, and that is one part of the AEO concept." Consequently, the condition monitoring, which helped monitor the bearings to identify requirements such as the need for maintenance, was combined with educating customers about the potential of condition monitoring.

To make the service offering more attractive, SKF acquired firms with consulting competencies, and broadened its AEO to include maintenance strategy. The latter move opened up a new range of possible services, such as SKF taking responsibility for the overall maintenance in a production plant and not being limited to the maintenance of its own products.

To make services more visible, they were made fee-based by separating the pricing of products and services. SKF introduced key account managers for services, whose personal relationship with customers became central. Another part of the success of the AEO concept, according to an interviewee, was the SKF culture: "I think the key is that our base is not bearings but to solve problems, and how you do it - that is not so [important]." The key is to solve customer problems, albeit not necessarily with a bearing.

\section{Parts-on-Line at Volvo Buses}

The idea with Parts-on-Line was that customers should have direct access, through an Internet portal, to Volvo Parts' supply system. This meant that customers could order parts at any time without having to wait until the dealers and workshops were open. The aim of the service was to improve accessibility, lower costs, and increase sales and profitability. Due to a tradition of providing services for free and charging only for products, Volvo Buses has experienced a certain degree of skepticism about services. However, Parts-on-Line was closely connected to physical spare parts, and the 
likelihood that the service would increase sales of these parts led to greater acceptance of the service. One interviewee explained: "No it cannot be done, no it cannot be sold ... but it increases the sales of spare parts and they can see the whole catalogue and it increases the speed of distribution ... Yes, we can probably charge for the service." This quotation shows how the managers' attitudes towards the service innovation changed over time.

The technical solution of Parts-on-Line has its origins in a large-scale project to create an e-business system. Following the project's completion, key company personnel felt that the technology and knowledge could be used as the basis for developing a new service. The company did not have the necessary resources at the time, so funding was obtained from other organizational units at Volvo that would benefit from the service. Although a formal development project was created for Partson-Line, the project did not follow the NSD process. A business case was created, but the development was mainly performed ad hoc, led by a group of six people.

Once the technology had been developed, the solution was tested with a key customer, whose experiences were used as a pilot case for implementing the solution for other customers. In the pilot case, the intended solution had to be customized to the information systems at the customer. The first installations involved a great deal of customization, but these projects were later used to further develop the service and improve the speed of the implementation and the service quality.

Once an installed base of systems had been created, Volvo Buses could start bundling this service with other services, such as optimization of the spare parts at the customer, maintenance contracts and fuel services. One manager explains the logic as follows: "Many customers have too many spare parts in stock and we can help them with a service where we give them advice on what spare parts to have and then we can 
lower their stock levels". By bundling services and reducing the customers' capital expenditures, the aim was to introduce new business models for services that complemented the present business model of providing services for free.

\section{Fuelwatch at Volvo Trucks}

The idea of Fuelwatch was to reduce customers' fuel consumption, thereby cutting costs. This was achieved through a combination of six individual services that were packaged and sold under the Fuelwatch brand. The individual services addressed optimization of the truck (for example, correct tires), regular services, fuel-saving accessories, monitoring of truck efficiency, education of drivers in fuel-efficient techniques, and, finally, fuel management audits. In other words, the services are not limited to the truck per se, but also include generic skills such as fuel-efficient driving. All of the individual services already existed prior to the launch of Fuelwatch, but were offered by different units within Volvo Trucks. Furthermore, the services were not standardized, which meant they were delivered in different ways to different markets.

Prior to the launch of Fuelwatch, an online program for surveillance of truck efficiency was developed; this was a new concept to the firm. Offering the six individual services under the common Fuelwatch brand gave the customer offerings structure and made them easier to market. As one interviewee put it: "I view Fuelwatch as a marketing name to package and sell services." One challenge of developing Fuelwatch was to secure service quality by educating the staff to offer a standardized and formalized service.

Initially, a small number of enthusiastic individuals were given a small budget to develop the idea of Fuelwatch. The work gained acceptance after a few months and developed into a formalized project. Fuelwatch was developed within a business unit 
that was responsible for sales and customer support, and therefore did not have service development as its main area of responsibility. The development was performed in this business unit, as the people who came up with the idea and were enthusiastic about developing it were working there at the time.

Although the development of Fuelwatch was an official, formalized project, it did not follow a structured development process. When new trucks are developed, services are generally included in that development project; that is, a complete offer is developed that essentially follows the same process. As services are closely related to the trucks, the perception is that products and services should be developed in an integrated manner. In the case of Fuelwatch, however, the development process for products was deemed to be unsuitable, based on a view that ideas for new services appear in an ad hoc manner with short development times.

\section{ANALYSIS}

The three service innovations were developed separately from the products; however, NSD was tightly linked to NPD. The service innovations were not developed from start to finish in a single project; instead, they evolved through several projects over time. SKF, Volvo Buses, and Volvo Trucks had structured NSD processes, but none of the service innovations was developed following these processes. The NSD processes in place at these firms were closely linked to, or constituted adaptations of, the NPD processes.

Based on our empirical investigation, it appears more likely that structured NSD processes are applied if services and products are developed separately than if NSD is integrated with NPD. Innovation modes (Gallouj and Weinstein, 1997) and the reverse product cycle (Barras, 1986) can help explain why it is harder for manufacturing firms to structure the NSD process if it is integrated with NPD. However, none of the three 
service innovations studied here followed the reverse product cycle. Instead, each service innovation followed an individual trajectory of innovation modes (see Toivonen and Tuominen, 2009). This suggests that, as products and services follow different trajectories of innovation modes, there can be a reason performing separated service development (Gebauer et al., 2008).

The NPD process is designed to support a trajectory of innovation modes for products and, as argued, services may follow a different trajectory. In the case of integrated service development, the NPD process is often used as a basis for an integrated development process. Consequently, the development process was not perceived as useful for NSD and was not followed in the cases studied. This argument is supported by the empirical observation that the development process was more structured when NSD was performed separately from NPD. In such a case, the development process could be designed to support specific innovation modes or to have inherent flexibility to support various trajectories of innovation modes. The better fit between the innovation mode and the NSD process should result in a higher success rate for services that are developed separately from products.

The three service innovations mentioned earlier are analyzed based on the different innovation modes suggested by Gallouj and Weinstein (1997). In Figure 2, the development of each of the three service innovations is captured through a trajectory of innovation modes. AEO developed over a long period of time. In the first phase, a radical innovation was created. SKF gave high priority to developing condition monitoring, a new competence for SKF as a provider and a new set of technological characteristics. At the same time, maintenance services were developed to solve a specific customer problem; that is, an ad hoc innovation. The connection between the two areas was made in the second phase. Maintenance services and condition 
monitoring were bundled in a re-combinative innovation, as a means of getting the systems to market. In this case, the recombinative innovation was created as a combination of characteristics of two services. Eventually, the AEO concept was refined in a formalization innovation mode; AEO was prepared to be offered and sold separately.

Parts-on-Line was initiated through a radical innovation that provided new technology and knowledge. This radical innovation provided a platform upon which the service could be further developed over time. This development took place through ad hoc innovations at a pilot customer and through customization of the service. Implementation at the first pilot customer was followed by implementation at two more pilot customers, and the customization of the service in these projects contributed, through ad hoc innovations, to further development of the service. Through a large number of implementations of the service, the service went through an improvement innovation mode with further refinement. Finally, a recombinative innovation mode was entered, as the service provider started to bundle Parts-on-Line with other services into an offering.

Fuelwatch started with the development of technology-based services that were new to both the firm and most of its customers. A main component of Fuelwatch was an online program for surveillance of truck efficiency, which is an example of a radical innovation with new technical characteristics. Later a number of existing services were bundled with the on-line surveillance program and sold under the name Fuelwatch. A recombinative innovation was created as a combination of characteristics of several services (Gallouj and Savona, 2009). Finally, the service was continuously improved through standardization and modification, following a formalization innovation mode. 
AEO and Parts-on-Line both underwent ad hoc innovation. In the ad hoc innovation mode, factors other than the structured NSD process were critical. As the ad hoc innovations departed from a specific customer problem, factors such as service orientation and ability to identify and solve customer problems were critical. All three service innovations were driven by ICT technology that enabled the service innovation, although this was not sufficient in itself to succeed in the market; simply getting the technology right did not sell any services. The reverse product cycle was developed specifically for technology-based services (Barras, 1986), but it still does not capture the phenomenon described in the three in-depth case studies. The empirical evidence seems to support the argument that there are alternative trajectories that a service innovation can follow before being introduced at the market in its final form.

\section{DISCUSSION AND CONCLUSIONS}

In general, this paper contributes to the relatively rudimentary literature on NSD in manufacturing firms (Kindström and Kowalkowski, 2009) by emphasizing integrated NSD and NPD, the use of a structured NSD process (Gebauer et al., 2008) and innovation modes (Gallouj and Weinstein, 1997; Gallouj and Savona, 2009).

\section{Theoretical Implications}

Our research suggests that service innovations often follow a trajectory of innovation modes that is different from that of a product innovation, see Barras (1986). Many service innovations in manufacturing firms depend on products as platforms for value co-creation (Chesbrough, 2011). The product in question could be a radical innovation, while the service might be a recombinative innovation (Windahl et al., 2004). These two innovation modes require different types of support from a development process; that is, different processes and methods. For example, the NSD process supporting a recombinative service innovation must address specific service challenges, such as the 
role of customers and customer-employee interaction. For a radical product innovation, the development process must support the development of new technical characteristics. In a situation where the required support differs, a key to overcoming the inherent challenge is to actively involve employees in creating local acceptance of the development project and of the final service innovation (Kowalkowski et al., 2011). The observation that integrated service development (Gebauer et al., 2008) often is productcentered and designed for product based services explain the failure of the integration of NPD and NSD.

Our research suggests that services developed separately from products more often follow a structured NSD process, which is in contrast to previous findings of Gebauer et al. (2008). In addition, Gebauer's (2007) suggestion of a structured development process as a prerequisite for successful NSD is not valid for all innovation modes. The in-depth case studies suggest that ad hoc innovation modes are better supported by a service-oriented culture or an attitude of customer problem-solving. Better alignment of the development process and the specific innovation mode can help NSD to succeed. We suggest that the success factor for service development is the fit between different innovation modes and the NSD process, rather than the NSD process per se (see also Gebauer et al., 2010).

Windahl et al. (2004) identified recombinative innovation as a role model for service innovation. The recombinative mode has been critical for the three service innovations, but it has been preceded by other innovation modes. All service innovations were based on ICT technology, and the starting point was a radical innovation mode in which new technology was developed. For two service innovations, the ad hoc innovation mode was early in the trajectory of innovation modes, supporting Kindström and Kowalkowski's (2009) and Gremyr et al.'s (2010) arguments that many 
service innovations come from solving specific customer problems in a customer relationship. Although ad hoc innovations challenge the principle that innovations have more than one specific application (Schumpeter, 1974), these are critical in a trajectory of innovation modes ending up in a service innovation.

This research adds to the research on innovation modes by suggesting that it is not sufficient to focus on a single innovation mode. The in-depth case studies show that the trajectory of innovation modes was key to successful service innovations. But, even though the investigated service innovations are based on ICT-technology, we identify trajectories of innovation modes that are different from the reverse product cycle (Barras, 1986). While the reverse product cycle concerns the trajectories of innovation throughout the lifecycle of a service, our observations cover trajectories that start before a service enters the market and continues until a service is well established on the market. Because of the limited number of cases underlying this study, further research is needed to understand which trajectories are more common and how firms can support these trajectories with appropriate development processes.

\section{Managerial Implications}

NSD processes often build on adaptations of NPD processes. This means that the stages, methods, and gate criteria in NSD were initially designed for products without properly accounting for the inherent differences between products and services. In practice, service developers often perceive the development process as an obstacle, and therefore do not use it. This is one explanation for the infrequent use of NSD processes in manufacturing firms.

It has been argued that service innovation must be supported by a structured NSD process (Gebauer et al., 2006). However, manufacturing firms must also look at the mode of specific service innovations in order to develop processes that support service 
innovation. Rather than supporting a service with just one process, there must be several development processes, depending on the innovation mode. It is essential to create a fit between development processes and innovation modes. Ad hoc innovations, for example, often originate in an on-going customer relationship and require a basic support structure, which might include service culture, a knowledge management system, tools to develop a business case, and slack time for NSD personnel. For other innovation modes, such as improvement and incremental innovation, a more traditional development process is suitable. Here, development methods and tools such as service blueprinting, Quality Function Deployment (QFD), and customer surveys can be used. For recombinative innovation and formalization innovation, the required level of support relates to issues such as business models, service modules, standardization, and bundling strategies.

\section{REFERENCES}

Alam, I. and Perry, C. (2002), "A Customer-Oriented New Service Development Process,” Journal of Services Marketing, Vol. 16 No. 6, pp. 515-534.

Barras, R. (1986), “Towards a theory of innovation in services,” Research Policy, Vol. 15 No. 4, pp.161-173.

Berry, L. L., Shankar, V., Parish, J. T., Cadwallader, S., and Dotzel, T. (2006), "Creating new markets through service innovation," Sloan Management Review, Vol. 47 No. 2, pp. 56-63.

Bryman, A. (1988), Quantity and Quality in Social Research, Routledge, London.

Bettencourt, L. A. And Brown, S. (2013), "From goods to great: Service innovation in a product-dominant firm", Business Horizons, in press. 
Chen, J., Tsou, H., and Huang, Y. (2009), "Service delivery innovation: Antecedents and impact on firm performance," Journal of Service Research, Vol. 12 No. 1, pp. $36-55$.

Chesbrough, H. (2011), Open Services Innovation, Jossey-Bass, San Francisco, CA.

Dubois, A. and Gadde, L.-E. (2002), "Systematic combining: An abductive approach to case research," Journal of Business Research, Vol. 55 No. 7, pp. 553-560.

Eisenhardt, K.E. (1989), "Building theories from case study research," Academy of Management Review, Vol. 14 No. 4, pp. 532-550.

Fischer, T., Gebauer, H., Gustafsson, A., and Witell, L. (2009), "Managerial recommendations for service innovations in different product-service systems," in Sakao, T. and Lindahl, M. (Eds.), Introduction to Product-Service Systems, Springer, London, pp. 237-258.

Fundin, A., Witell, L. and Gebauer, H. (2012), "Service transition: finding the right position on the goods-to-services continuum," International Journal of Modelling in Operations Management, Vol. 2 No. 1, pp. 69-88.

Gadrey, J., Gallouj, F., and Weinstein, O. (1995), "New modes of innovation: How services benefit industry," International Journal of Service Industry Management, Vol. 6 No. 3, pp. 4-16.

Gallouj, F. and Weinstein, O. (1997), "Innovation in services," Research Policy, Vol. 26 No. 4-5, pp. 537-556.

Gallouj, F. and Savona, M. (2009), "Innovation in services: A review of the debate and a research agenda," Journal of Evolutionary Economics, Vol. 19 No. 2, pp. 149172. 
Gebauer, H. (2007), “An investigation of antecedents for the development of customer support services in manufacturing firms," Journal of Business-to-Business Marketing, Vol. 14 No. 3, pp. 59-96.

Gebauer, H., Friedli, T., and Fleisch, E. (2006), “Success factors for achieving high service revenues in manufacturing firms," Benchmarking, Vol. 13 No. 3, pp. 374386.

Gebauer, H., Krempl, R., Fleisch, E., and Friedli, T. (2008), "Innovation of productrelated services," Managing Service Quality, Vol. 18 No. 4, pp. 387-404.

Gebauer, H., Edvardsson, B., Gustafsson, A., and Witell, L. (2010), "Match or mismatch: Strategy-structure configurations in the service business of manufacturing companies," Journal of Service Research, Vol. 13 No. 2, pp. 198215.

Gebauer H., Gustafsson, A., and Witell, L. (2011), "Competitive advantage through service differentiation by manufacturing companies," Journal of Business Research, Vol. 64 No. 12, pp. 1270-1280.

Gremyr, I., Löfberg, N., and Witell, L. (2010), “Service innovations in manufacturing firms," Managing Service Quality, Vol. 20 No. 2, pp. 161-175.

Griffin, A. (1997), "PDMA Research on New Product Development Practices: Updating Trends and Benchmarking Best Practices," The Journal of Product Innovation Management, Vol. 14 No. 6, pp. 429-458.

Gustafsson, A., Brax, S., and Witell, L. (2010), "Setting a research agenda for service business in manufacturing industries," Journal of Service Management, Vol. 21 No. 5, pp. 557-563. 
Gustafsson, A., Kristensson, P. and Witell, L. (2012), “Customer co-creation in service innovation: a matter of communication?," Journal of Service Management, Vol. 23 No. 3, pp. 311-327.

Hsu, Y. (2011), “Design innovation and marketing strategy in successful product competition," Journal of Business \& Industrial Marketing, Vol. 26 No. 4, pp. $223-236$.

Kindström, D. and Kowalkowski, C. (2009), "Development of industrial service offerings: A process framework," Journal of Service Management, Vol. 20 No. 2, pp. 156-172.

Kowalkowski, C., Kindström, D., and Brehmer, P. (2011), "Managing industrial service offerings in global business markets," Journal of Business \& Industrial Marketing, Vol. 26 No. 3, pp. 181-192.

Kowalkowski, C., Kindström, D., Brashear, T. G., Brege, S., Biggeman, S. (2012), "Service infusion as agile incrementalism in action", Journal of Business Research, Vol. 65 No. 2, pp. 765-772.

Kowalkowski, C., Witell, L. and Gustafsson, A. (2013), “Any way goes: Identifying value constellations for service infusion in SMEs", Industrial Marketing Management, Vol. 42 No. 1, pp. 18-30.

Lancaster, K.J. (1966), “A new approach to consumer theory,” Journal Political Economy, Vol. 14, pp. 133-156.

Martin, C.R. Jr. and Horne, D.A. (1992), "Restructuring towards a service orientation: The strategic challenges," International Journal of Service Industry Management, Vol. 3 No. 1, pp. 25-38. 
Mathieu, V. (2001), "Product services: From a service supporting the product to a service supporting the client," Journal of Business \& Industrial Marketing, Vol. 16 No. 1, pp. 39-58.

Meredith, J. (1998), "Building operations management theory through case and field research," Journal of Operations Management, Vol. 16 No. 4, pp. 441-454.

Möller, K. Rajala, R. and Westerlund, M. (2008), "Service innovation Myopia? A new recipe for client-provider value creation," California Management Review, Vol. 50 No. 3 , pp. $31-48$

Neu, W.A. and Brown, S.W. (2005), "Forming Successful Business-to-Business Services in Goods-Dominant Firms," Journal of Service Research, Vol. 8 No.1, pp. $3-17$.

Oliva, R. and Kallenberg, R. (2003), "Managing the transition from products to services," International Journal of Service Industry Management, Vol. 14 No. 2, pp. 160-172.

Ostrom, A.L., Bitner, M.J., Brown, S.W., Burkhard, K.A., Goul, M., Smith-Daniels, V., Demirkan, H., and Rabinovich, E. (2010), "Moving forward and making a difference: Research priorities for the science of service," Journal of Service Research, Vol. 13 No. 1, pp. 4-36.

Salunke, S, Weerawardena, J. and McColl-Kennedy, J. R. (2011), "Towards a model of dynamic capabilities in innovation-based competitive strategy: Insights from project-oriented service firms," Industrial Marketing Management, Vol. 40 No. 8, pp. 1251-1263. 
Santamaría, L., Jesús Nieto, M. And Miles, I. (2012), "Service innovation in manufacturing firms: Evidence from Spain”, Technovation, Vol. 32 No. 2, pp. $144-155$.

Saviotti, P.P. and Metcalfe, J.S. (1984), “A theoretical approach to the construction of technological output indicators," Research Policy, Vol. 13, pp. 141-151.

Siggelkow, N. (2007), "Persuasion with case studies," Academy of Management Journal, Vol. 50 No. 1, pp. 20-24.

Schumpeter, J.A. (1974), The Theory of Economic Development, New York, N.Y. (reprint): Oxford University Press.

Toivonen, M. and Tuominen, T. (2009), "Emergence of innovations in services," Service Industries Journal, Vol. 29 No. 7, pp. 887-902.

Ulaga, W. and Reinartz, W. (2011), "Hybrid Offerings: How Manufacturing Firms Combine Goods and Services Successfully," Journal of Marketing, Vol. 75 No. 6, pp. 5-23.

Vargo, S.L. and Lusch, R.F. (2004), "Evolving to a New Dominant Logic for Marketing," Journal of Marketing, Vol. 68, pp. 1-17.

Vargo, S.L. and Lusch, R.F. (2008), "From goods to service(s): Divergences and convergences of logics," Industrial Marketing Management, Vol. 37, pp. 254259.

Windahl, C., Andersson, P., Berggren, C., and Nehler, C. (2004), "Manufacturing firms and integrated solutions: Characteristics and implications," European Journal of Innovation Management, Vol. 7 No. 3, pp. 218-228. 


\section{FIGURES}

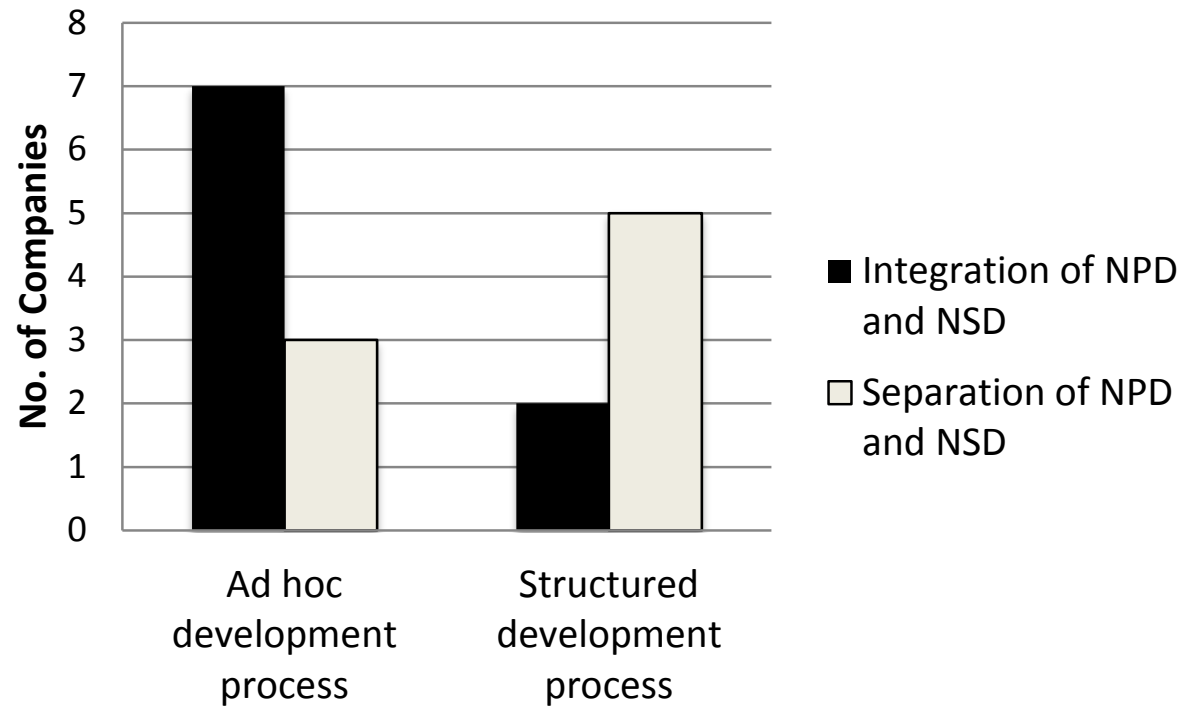

Figure 1: Integration and separation of service development in relation to the structure of service development. 
a)

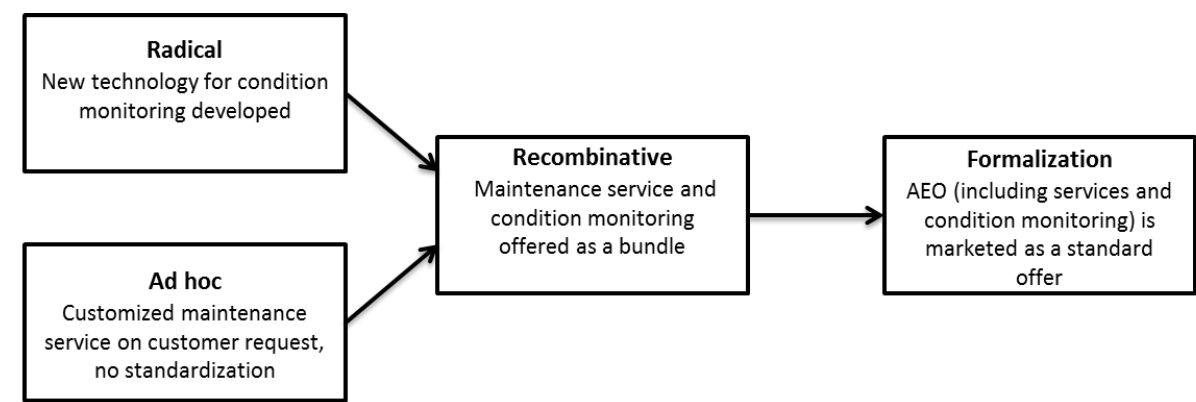

b)

\begin{tabular}{|c|c|c|c|}
\hline \begin{tabular}{l}
\multicolumn{1}{c}{ Radical } \\
Development of new \\
e-business platform
\end{tabular} & $\begin{array}{l}\text { Ad hoc } \\
\text { Adaption of the e-business } \\
\text { platform to a specific } \\
\text { service, i.e. Parts-on-Line, } \\
\text { at one customer site }\end{array}$ & $\begin{array}{c}\text { Improvement } \\
\text { Parts-on-Line continuously } \\
\text { improved and installed at } \\
\text { customers }\end{array}$ & $\begin{array}{c}\text { Recombinative } \\
\text { Parts-on-Line further } \\
\text { developed through bundling } \\
\text { with other services }\end{array}$ \\
\hline
\end{tabular}

c)

\begin{tabular}{|c|c|c|}
\hline $\begin{array}{c}\text { Radical } \\
\text { Development of an } \\
\text { on-line program for } \\
\text { surveillance of truck } \\
\text { efficiency }\end{array}$ & $\begin{array}{l}\text { Recombinative } \\
\text { On-line program for } \\
\text { surveillance and other } \\
\text { services bundled and } \\
\text { offered as Fuelwatch }\end{array}$ & $\begin{array}{l}\text { Formalization } \\
\text { Fuelwatch continuously } \\
\text { improved through } \\
\text { standardization }\end{array}$ \\
\hline
\end{tabular}

Figure 2: Trajectories of innovation modes for ${ }^{\text {a) }} \mathrm{AEO}$ at SKF, ${ }^{\text {b) }}$ Parts-on-Line at Volvo Buses, and ${ }^{\mathrm{c})}$ Fuelwatch at Volvo Trucks. 